Al-Huquq: Journal of Indonesian Islamic Economic Law, 2 (1), 2020: 48 - 73

ISSN: 2715-0003; E-ISSN 2714-5514

DOI: http://dx.doi.org/10.19105/al-huquq.v1i2.3555

\title{
Pembiayaan Istishsna' dan Implementasinya di Perbankan Syariah
}

\author{
Suaidi, Lukmanul Hakim \\ (Institut Agama Islam Negeri Madura, Jl. Raya Panglegur KM. 04 \\ Pamekasan-69371, Jawa Timur Indonesia)
}

\begin{abstract}
Abstrak
Tulisan ini membahas tentang pembiayaan istishna' dan beberapa persoalan yang menyertainya dalam praktik perbankan syariah di Indonesia. Pembiayaan istishna' ini adalah produk berbasis jual beli yang tidak jarang dipraktikkan oleh perbankan syariah masa kini. Dalam studi ini, dapat ditarik beberapa kesimpulan yang menyatakan bahwa; Pertama, salah satu pembiayaan yang berbasis jual-beli dalam bentuk bai' adalah Istishna' yang disebut sebagai akad pesanan pada suatu barang dari shani' kepada mustashni'; Kedua, Atas dasar istihsan secara hukum istishna' merupakan akad yang boleh dipraktikkan oleh perbankan; Ketiga, secara umum implementasi yang dilakukan perbankan syariah pada masyarakat adalah bisa berbentuk pembangunan proyek perumahan, pesanan sepeda motor, token listrik, gedung sekolah, dll; Keempat, masalah dalam Pembiayaan Istishna' ini salah satunya adalah terlihat pada kurang inovatifnya dalam praktik lapangan, cenderung kaku dan tidak fleksibel karena pembiayaan yang bersifat jangka pendek. [This paper discusses istishna financing 'and some of the problems that accompany it in sharia banking practices in Indonesia. Istishna financing 'is a sale-based product which is not infrequently practiced by Islamic banking today. In this study, several conclusions can be drawn stating that; First, one of the financing based on buying and selling in the form of bai 'is Istishna' which is called an order contract on an item from shani 'to mustashni'; Second, on the basis of istihsan legally istishna 'is a contract that may be practiced by banks; Third, in general, the implementation carried out by Islamic banking to the public is in the form of housing construction projects, motorcycle orders, electric tokens, school buildings, etc .; Fourth, the problem in Istishna Financing 'one of which is
\end{abstract}

https://creativecommons.org/licenses/by-nc/4.0/

Copyright (c) 2019 by al-huquq. All Right Reserved

Author Correspondence: suaidisyafiie1922@gmail.com 
seen in the lack of innovation in field practice, tends to be rigid and inflexible because of short-term financing].

Kata Kunci:

Bai'; Akad; Istishsna'; Perbankan Syariah

\section{Pendahuluan}

Dalam menjalankan bisnis, perbankan syariah bisa melalui tiga model pembiayaan; bagi-hasil, jual-beli, dan sewa menyewa. Dalam model jual-beli (bai') ini secara umum dapat dibagi menjadi tiga bagian, pertama, Model jual-beli dengan sistem menjual sesuatu yang barangnya sudah dalam kuasa si penjual sehingga pasca-transaksi si pembeli akan menerima langsung pada barang yang diperjual-belikan diantara keduanya; kedua, Model jual-beli dalam bentuk menjual sesuatu yang belum dalam kuasa si penjual, hal ini dapat dilakukan berbentuk pesanan. Namun hal ini ada risiko tersendiri yang harus ditanggung oleh penjual bahwa akan ada jaminan akan adanya barang di kemudian hari. Terkait sistem pembayarannya bisa disepakati dan dilakuan di awal atau diakhir transaksi; Ketiga, Model jual-beli yang bentuk barangnya tidak ada dan tidak bisa dipesan, seperti bertransaksi membeli ikan dalam lautan atau membeli burung yang terbang sehingga transaksi ini secara hukum fiqih haram dilakukan karena barang selain barang belum ada dalam kuasa penjual juga barang yang ingin diperjual-belikan tidak diketahui pemiliknya.

Salah satu bentuk aplikasi jual beli dalam perbankan syariah, yaitu pembiayaan istishna'. Eksistensi Pembiayaan istishna' merupakan Pembiayaan yang tidak jauh beda dengan Pembiayaan salam di mana Pembiayaanistishna' ini berbentuk pesanan yang intermediary-nya perbankan syariah. Perbankan syariah atau biasa disebut dengan shani' (pemesan) melakukan perjanjian barang sesuai pesanan. Jadi, Pembiayaan Istishna' merupakan bentuk menempah sesuatu yang dilakukan shani' 
kepada mustashni'. Bentuk tempahan ini bisa berbentuk barang, seperti ikan, pakaian seperti sarung, ruko, kendaraan seperti mobil, sepeda motor atau kendaraan lainnnya, dan lainnya. Jadi, Istishna' merupakan satu model yang hakikatnya telah dipraktikkan sejak era Rasulullah Saw. dan sahabat-sahabat beliau. Ironisnya, masih banyak masyarakat yang kurang memperhatikan pada wujud produk ini, sehingga masyarakat cenderung keliru baik secara teori maupun praktiknya. Dalam kajian ini, penulis akan menjelaskan tentang Pembiayaan istishna', baik dari segi teori, aplikasi, pembiayaan dan implementasi dan beberapa masalah yang menyertainya di perbankan syariah.

\section{Kerangka Teori}

Istishsna' itu muncul dari lisan arab diambil dari shana' $a^{\prime}$ yashna'u shun'atan dengan orientasi arti amilahu yang artinya membuat, berbuat, melakukan dan mengerjakan. ${ }^{1}$ Istishsna' secara bahasa adalah bermula dari awal kata istahna'a yastahni'u isthisna'an di mana dalam kata ini mengandung makna litthalabah, yang berarti "menyuruh membuatkan". Makna ini berkonotasi dengan kata al-mustashni' yang memiliki arti pengusaha pabrik, menjadikan sesuatu, menghasilkan dengan tangan atau mesin (manufacture) ${ }^{2}$. Jadi, Istishna' dari sudut bahasa bermaksud menyuruh seseorang atau perusahaan untuk dibuatkan sesuatu sesuai keinginan dari pemesan awal. Dalam analogi lain, menjadikan atau menghasilkan suatu barang berdasar pada permintaan dari pemesan.

Secara terminologi Istishsna' adalah akad jual-beli yang dilakukan antara penjual pertama yang disebut pemasok (al-

1 Ali Ahmad As-Salus, Musi'ah al-Qadaya al-fighiyah al-Muashirah waliqtishad al-Islami (Mesir: Badrul Kutub al-Mishriyah, 2006), hlm. 817.

2 Ilyas Anton Ilyas, al-qomus al-ashri (Shunduq Barid, 954), hlm 381, istilah (mustashni') ini mengandung arti "pengusaha pabrik" bisa di lihat di, Ahmad Warson Munawwir, Kamus al-Munawwir Arab-Indonesia Terlengkap (Yogyakarta: Ikapi, 1997), cet. Keempat belas, hlm. 797. 
shani') dengan penjual akhir (almushtashni'). Dalam pembiayaan Istishsna' ini ada pesanan suatu barang kepada pemasok, sehingga pemasok menghasilkan suatu barang atau disebut almashnu' (pokok) dalam bentuk karya sendiri atau diproduksi oleh pihak lain sesuai spesifikasi dan klausul yang disepakati antara pemasok (al-shani') dengan penjual akhir (almushtashni') sehingga al-mashnu' yang dihasilkan sesuai pesanan sebagaimana kontrak yang disepakati di awal. Terkait harga dilakukan sebagaimana kesepakatan apakah akan dilakukan dalam bentuk cicilan atau melakukan penangguhan terhadap pembayaran. ${ }^{3}$

Dalam istilah lain, bai' al-istishna' merupakan akad jual beli yang dilakukan antara pembeli barang dengan penghasil barang. Dalam hal ini, pembeli akan melakukan pesanan kepada pemporduksi barang sehingga produsen tersebut menerima pesan dan menghasilkan barang sebagaimana pesan yang diterima dari pemesan. Artinya, yang berkeinginan untuk membeli barang berupaya untuk mencari pihak lain dalam rangka memperoleh barang sesuai kriteria yang diinginkan dan diperjanjikan untuk dijual kepada pembeli akhir. Sistem pembayaran dapat dilakukan dengan cara dibayar di awal, dicil atau dapat dilalui dengan menangguhkan pembayaran dan dibayar di waktu mendatang ketika barang sudah ada dalam kuasa pemesan. ${ }^{4}$

Oleh karena itu, dalam praktik bai' istishna' ini ketika pembeli telah melakukan pesanan pada penghasil barang maka penghasil barang harus melakukan upaya untuk mengahasilkan barang menurut keinginan dan kriteria untuk memuaskan pembeli akhir. Hal ini untuk meminimalisir risiko pembatalan

3 Hendi Prabowo. Heri Sudarsono, Istilah-istilah Bank dan Lembaga Keuangan Syariah (Yogyakarta: UII Press, 2006), cet keempat, hlm. 58-59.

${ }^{4}$ Muhammad Syafiie Antonio, Bank Syariah (Jakarta: Ikapi, 2011), cet. Kedelapan, hlm. 113. Atau penjelasan ini bisa dilihat juga di, Abu Bakar Ibnu Mas'ud al-Kasani, al-Bada'i was Sana'i fi Tartib al-Shara'i (Bairut: Darul Kitab al-Arabi), edisi ke-2. 
pada barang yang dipesan oleh pembeli akhir. Kesepakatan pembayaran uang pada barang pesanan sesuai kesepakata yang dibangun diantara keduanya bisa dibayar dimuka, dicil, melakukan penangguhan sehingga pembayarannya bisa dilakukan pada waktu mendatang. ${ }^{5}$

\section{Dasar Hukum Istishna'}

Pemahaman para ahli fiqih, hukum yang terikat pada bai' salam mayoritas juga terikat pada mel bai' istishna'. Bai' alistishna' adalah suatu transaksi akad yang secara zdahir hukum mirip dengan bai' salam. Sehingga, ulama ahli fiqih banyak mengeluarkan fatwanya terrkait "keshahihah" pada bai' alistishna' ini. Hal ini sebagaimana para ahli fiqih berpendapat: 6

Hanafiyah mengomentari akan bolehnya menggunakan PembiayaanIstishna', alasan mereka dijelaskan sebagaimana berikut:

1. Suatu ketika Nabi Muhammad Saw. pernah meminta untuk dibuatkan sebuah cincin dan mimbar.

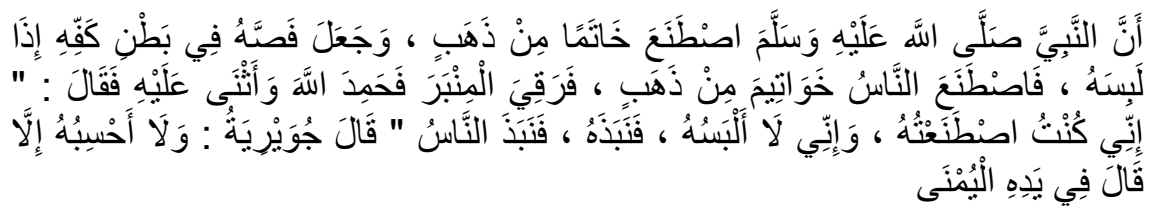

Artinya: "Sesungguhnya Nabi Saw. pernah meminta dibuatkan cincin dari emas, dan menghadapkan mata cincinnya ke telapak tangan beliau apabila beliau mengenakannya. Maka orang-orang pun ramai memesan cincin dari emas. Lalu beliau naik mimbar. Setelah memuji Allah dan menyanjung-Nya beliau bersabda: 'Sesungguhnya saya telah meminta dibuatkan cincin dari emas, dan sungguh saat ini saya tidak akan mengenakannya.' Maka

${ }^{5}$ Nurul Hak, Ekonomi Islam Hukum Bisnis Syariah (Yogyakarta: Sukse Offset, 2011), hlm. 37-38.

${ }^{6}$ Ibid., hlm. 114. 
orang-orang pun membuang cincin mereka. Juwairiyah mengatakan; 'Aku tidak mengira lagi kecuali Nafi' mengatakan; 'Beliau mengenakannya di tangan kanan beliau." (HR. Bukhari)

2. Ijma Ulama menetapkan sebagai kerja sama (at-taamul). ${ }^{7}$

Golongan Imam Hanafi mendefiniskan kata istishna' ini yang berorientasi pada kategori menjual suatu barang dengan mencantumkan syarat tertentu. Dalam definisi yang disampaikan oleh mereka bahwa ada perbedaan antara bai' istishna' dengan bai' salam. Senada dengan golongan Imam hanafi yaitu argumen yang disampaikan oleh golongan Imam Hambali yang mengomentari bahwa tidak ada kesamaan diantara keduanya. Bahkan bagi golongan Imam Hambali mengartikan terkait bai' istishna' dengan bai' salam bahwa syarat diantara keduanya keduanya harus dialkukan. Berbeda dengan golongan yang dikeluarkan fatwanya dari madzhab Imam Maliki dan Imam Syafiie yang justeru menyatakan bahwa keduanya sama antara bai' istishna' dengan bai' salam. Kesamaan ini karena keduanya samasama masuk pada ketegori perniagaan dalam bentuk pesanan atau menempah barang untuk mengashilkan sesuai pesanan dari pemesan awal. Hal yang sedikit membedakan karena bai salam hanya lebih umum dari pada bai' istishna' dengan bai' salam bai' istisna' karena faktor kehususan barang pesanan yang diinginakn oleh pemesan dalam bai' istishna' ini lebih spesifik, khusus dan unik.

Imam Maliki dalam kitabnya, beliau tidak secara jelas menjelaskan istishna', beliau hanya memberikan keterangan selaras dengan hadits yang ada pada akad salam baik dasar itu yang terkait dengan syarat maupun hukumnya. Sedangkan Syafiiyah tidak memuat sama sekali yang berhubungan dengan istishna' kalau Imam Syafiie sendiri dalam kitab alUmmnya misalkan kita lihat dalam bab as-salaf, di mana

${ }^{7}$ (Al-Syirazi, al-Muhazdab (tp, tt), jilid 12, hlm. 121.) 
penjelasannya sebagaimana Imam an-Nawawi dalam kitab Raudlatut Thalibin yang membolehkan akad salam (Imam asSyafiie menyamakan dalam kitabnya antara bai' istishna' dengan bai' salam) misalkan yang penting disebutkan jenis dan panjangnya. Namun, ada di dalam akad salam yang ditetapka Imam an-Nawawi ini yang tidak dibolehkan menggunakan akad salam misalkan memesan Biji-bijian seperti Qizan dan Thanajir. Pendapat Imam an-Nawawi ini berbeda dengan pendapatnya al-Syrazi yang mengatakan boleh menggunakan akad salam walaupun itu bentuknya biji-bijian, buah-buahan maupun baju.

3. Istihsan. $^{8}$

Dalam istihsan ini berdasarkan hadits Rasulullah Saw yang bersabda:

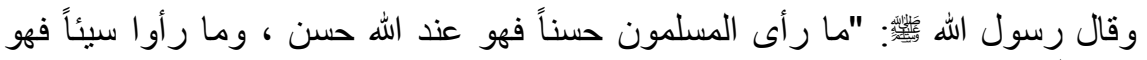

$$
\begin{aligned}
& \text { عند الله سيء" }
\end{aligned}
$$

Artinya: "dan Rasulullah Saw. bersabada: apa yang telihat bagi orang muslim baik maka di sisi Allah juga baik, dan apa yang apa yang telihat bagi orang muslim itu jelek maka di sisi Allah juga jelek" (HR. Imam Baihaqi)

${ }^{8}$ Dalam hal ini Ulama hanafi menyatakan pendapat bahwa istihsan merupakan dasar dari bai' istishna' ini, karena menyangkut adah (kebiasaan) masyarakat ketika ingin memperoleh sesuatu tapi tidak mampu memnghasilkannya. Ia juga berperanan memberikan kemudahan tentang urusan yang berhubungan berniaga terutama kepada umat umat Islam. Oleh demikian, prinsip qiyas dikaitkan dengan hadits Rasulullah Saw yang telah bersabda:

$$
\text { لا تجتمع أمتي على ضلالة }
$$

Artinya: "umatku tidak tidak boleh terkumpul atas (dasar) perkara kesesatan". Hal ini sebenarnya arti secara qiyasi; tidak boleh melakukan transaksi pertukangan sebab transaksi tersebut masuk pada transaksi jual beli yang tidak ada barang (maqdum). Nabi Muhammad Saw. sangat melarang terhadap hasil jual beli yang dalam transaksinya barang tidak dalam kuasa dari penjual. Ali Ahmad As-Salus,. Hlm. 816-829. 
Bai' al-istishna' perspektif mazhab Hanafi adalah transaksi yang tidak diperbolehkan karena secara hukum qiyas sangat kotradiktif dengan ghirah jual beli itu sendiri. Perspektif mereka, jual-beli harus dilakukan salahsatunya barang harus jelas dan dalam kuasanya, artinya harus tampak kala itu. Sedangkan dalam akad istishna' sendiri tidak masuk pada kategori itu, yaitu barang tidak terlihat setelah transaksi. Namun, golongan ini ada hukum yang disetujui yaitu berdasarkan landasan istihsan. Bagi mereka ada beberapa alasan sehingga dapat menyetujui akan eksistensi bai' istishna' ini:

1. Secara luas dan tidak dapat dibendung bahwa secarea riil, masyarakat sudah banyak mempraktikkan akad ini dan tanpa ada beban hukum sama sekali karena mudahnya dalam bertranksi. Sehingga tidak bisa dielakkan bahwa bai' istishna' ini merupakan hasil ijtima'i yang sumbernya dari praktik dari masyarakat itu sendiri.

2. Dalam ijma' ulama ada kemungkinan terjadinya pelanggaran pada hukum qiyas ini.

3. Dasar dari lahirnya bai' istishna' faktor terdesaknya kebutuhan masyarakat pada akad ini. Hal demikian karena tidak semua barang yang tersedia di riil market tersedia sesuai keinginan sehingga tidak boleh tidak harus mencari alternatif pembuat barang untuk dihasilkan sesuai keinginan.

4. Berdasarkan huku jual beli, bahwa boleh melakukan akad dan atau bertransaksi sesuatu sesuai kebutuhan selama tidak ada nash yang melarangnya. Oleh karena itu bai' istishna' boleh dilakukan karena tidak ada aturan dalam al-Qur'an atau al-Hadits yang tidak membolehkannya.

5. Ulama kontemporer atau era kini berpendapat bahwa akad ini boleh dilakukan berdsarkan qiyas dan kebiasaan masyarakat yang telah banyak dilakukan selama penjual sepakat bahwa mampu menghasilkan barang yang dipesan dan minimnya perselisihan di akhir karena telah 
disampaikan diawal terkait spesifikasi atau kriteria barang yang akan dipesan oleh pembeli/pemesan. ${ }^{9}$

\section{Ciri khas Produk Istishna'}

Bai' istishna' memiliki beberapa jenis kesamaan dengan bai' salam sebab diantara keduanya sama-sama tidak adanya barang ketika terjadi akad pesanan. Letak perbedaan mendasar antara bai' istishna' dengan bai' salam ini adalah kalau bai' salam adalah sistem pembayrannya harus diberikan di awal artinya dilakukan secara cash. Berbeda dengan bai' istishna' di mana pada akad ini bisa dilakukan dengan tidak kondisi atau waktu, di awal, dicicil atau dapat pula ditangguhkan sesuai kesepakatan antara pemesan dengan penjual barang. Letak kesamaan dengan pembiayaan yang lain selain dengan bai' salam ini yaitu sama dengan bai' ijarah, yaitu karena keduaduanya sama memanfaatkan tenaga kerja bagi kedua bai' tersebut. ${ }^{10}$ Namun letak perbedaan dari keduanya terletak kalau kalau bai' istishna' bahan atau barang mentahnya diberikan oleh pihak pemesan sedangkan dalam bai' ijarah ini tidak.

Adapun Aplikasi, Visi, Lokasi dan waktu pembagian Istishsna'dirinci sebagai berikut:

1. Pembiayaan Istishsna' dalam Aplikasi; Model pembiayaan istishsna' cenderung diterapkan untuk:; 1). Model Pembiayaan Modal Kerja; 2) Model Pembiayaan dalam bentuk penanaman modal, contohnya dilakukan dalam rangka mendatangkan mesin atau peralatan ketika ingin membuat barang dan agar mudah ketika mau menghasilkan

9 Hubungan dengan penjelasan istishna' ini, Syafiie Antonio meletakkan penjelasannya yang merujuk pada kitabnya Abdurrahman alJaziri, al-figh ala mazdahib al-arba'ah (Beirut: Darul Qalam), vol II, hlm.202. Lebih jelasnya lihat Muhammad Syafiie Antonio, Bank Syariah,. hlm. 114.

${ }_{10}$ Dwy Suwiknyo, Kamus Lengkap Ekonomi Islam (Yogyakarta: Total Media, 2009), hlm. 121-122. 
barang; 3) Model pembiayaan pada tata letak suatu bangunan atau lainnya;

2. Pembiayaan Istishsna' dalam memperoleh barang; modelmodel pada pembiayaan istishna' yang ini harus melakukan syarat-syarat tertentu sebagaimana berikut: 1). Wajib jelas jenis dan spesifikasi barangnya sehingga layak diklaim hutang; 2). Bagaimana sekiranya bisa diterangkan secara detail terkait spesifikasi barangnya; 3). Barang dilakukan dikemudian hari; 4). Ketika ingin menyerahkan barang maka waktu dan lokasi penyerahan barang harus ditentukan sebagaiamana kepakatan yang ditetapkan; 5) tidak boleh melakukan penjualan barang bagi pembeli pada barang sebelum barang betul-betul diterima oleh pembeli; 6) barang tidak diperkenankan ditukar dengan barang yang lain kecuali sesuai kesepakatan misalnya harus sejenis; 7). Ketika terjadi perbedaan terhadap barang yang dipesan artinya tidak sesuai spesifikasi maka pihak pemesan boleh melakukan dua opsi; melanjutkan atau membatalkan terhadap barang yang dipesan;

3. Istishsna' dalam bentuk Pembayaran; syarat yang harus dipenuhi dalam Istishsna' ini adalah; 1). Diketahuinya alat bayar baik dalam jumlah atau bentuknya apakah berupa manfaat atau justeru berbentuk uang; 2). Kesepakatan menjadi ciri khas sah dan tidaknya dalam model pembayaran; 3). Pembebasan hutang bukan solusi dalam model pembayaran pada pembiayaan ini.

4. Istishsna' dalam bentuk penyediaan Barang; ketika ingin menyerahkan dan barang sudah tersedia maka harus melakukan syarat sebagai berikut; 1). Pada saat barang dan waktu tidak sesuai kesepakatan atau spesifikiasi yang sudah disepakati maka pemesan dapat melakukan opsi sebagai berikut; a). Pesanan bisa jadi batal atau pemesan boleh memfasakh barang dan penjual misalkan pihak bank harus mengembalikan dana pemesan; b). Penyerahan barang yang tersedia bersifat menunggu; c). Boleh minta kepada pihak 
penjual/bank untuk mengganti pesanan sebagaimana barang yang diinginkan bisa dalam bentuk sejenis atau tidak selama nilai jual dan pasarnya sama seperti barang yang dipesan semula; 2). Ketika penjual/bank selesai membuat barang dan ternyata barang yang diserahkan misalnya lebih tinggi nilainya maka penjual tidak boleh meminta tambahan uang pada pemesan terkecuali ada keikhlasan atau kesepakatan di awal kontrak; 3). Atau sebaliknya, misalkan pada saat penjual/bank selesai membuat barang dan ternyata barang yang diserahkan lebih rendah nilainya maka nasabah boleh menuntut pihak penjual kecuali ada unsur kerelaan dari pemesan.

5. Istishsna' dalam tujuan pada Pembiayaan istishsna'; model ini dilakukan oleh penjual dengan memberikan dalam bentuk fasilitas untuk memenuhi kebutuhan pembiayaan bagi pembuat barang dengan metode pembayaran di awal secara bertahap.

6. Istishsna' dalam model bai' Ijarah dan bai' Murabahah walMu'ajjal; Model pembiayaan ini merupakan bentuk pembiayaan yang tersusun dengan tiga model pembayaran tunggal, yakni; model jual-beli istishsna', model bai' Ijarah dan model murabahah wal-mu'ajjal..11

11 Ahmad Ifham Sholihin, Buku Pintar Ekonomi Syariah (Jakarta: Kompas Gramedia, 2010), hlm. 359-361. 
Dalam pembiayaan istishna' juga mempunyai skema yang digambarkan sebagai berikut:

a. Pembiayaan istishna'

Skema pembiayaan istishna', ada dua ragam jenis pembiayaan ketika nasabah berposisi sebaagai pemesan barang: 12

1) Bank Syariah memilih Produsen;

2) Nasabah menunjuk atau memilih Produsen.

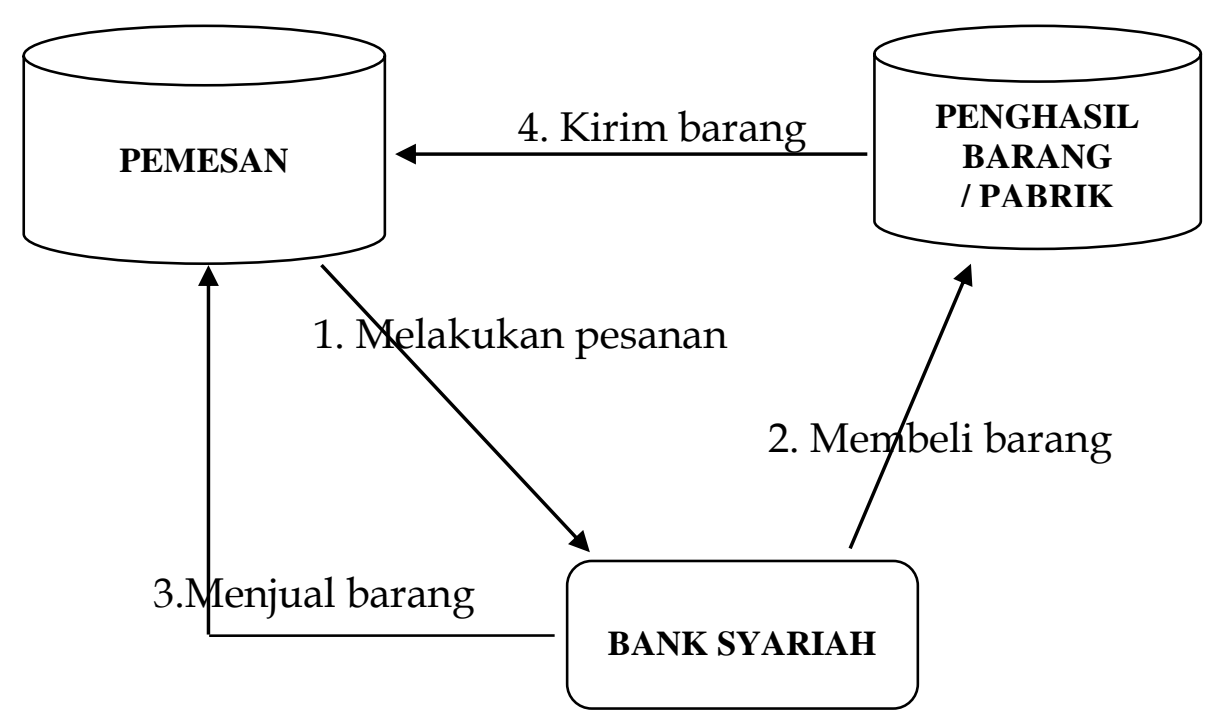

Skema 1.1

Model Pembiayaan bai' Istishna ketika Bank Syariah berposisi pemilih Produsen.

Penjelasan:

a. Sebagai penjual nasabah melakukan pesanan pada bank syariah kemudian dalam pesanan barang tersebut dengan rinci dijelaskan terkait kriteria atau spesifikasi barangnya, sehingga bank adalah berposisi sebagai

12 Ismail, Perbankan Syariah (Jakarta: Kencana Prenada Media Group, 2011), hlm. 147. 
penyedia barang terhadap pesanan barang dari nasabah.

b. Pasca penerimaan barang pesanan dari nasabah kemudian bank syariah memesan barang sesuai kriterianya kepada pembuat barang sehingga pemesan betul-betul menerima barang sesuai keinginannya dari bank syariah.

c. Setelah bak syariah menerima barang dari pembuat barang/produsen maka baru bank syariah menjual barang yang sudah diterima terebut kepada pemesan barang. Terkait harga adalah sesuai kesepakatan di awal.

d. Pasca barang sudah jadi $100 \%$ maka bank syariah tidak menyerahkan secara langsung kepada nasabah melainkan diberikan oleh produsen secara langsung kepada nasabah.

Skema 1.2 ketika Nasabah menunjuk atau memilih Produsen sendiri.

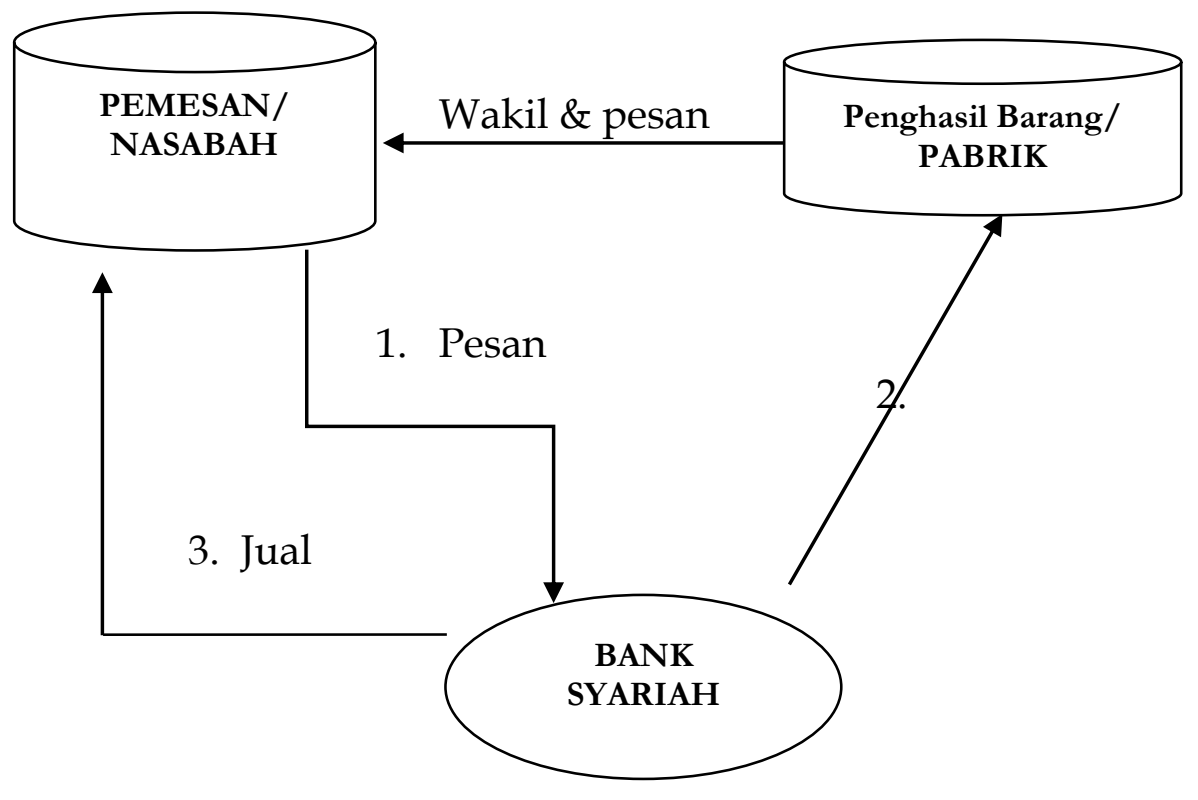


Penjelasan:

a. Posisi Pemesan/nasabah di sini adalah pemesan barang kepada bank syariah (penjual) dan bank sebagai wakil dari Nasabah kemudian bank syariah bertindak sebagi pemesan barang kepada penghasil barang atau pabrik.

b. Nasabah sebagai pembeli dan bank syariah sebagi penjual.

c. Pabrik menghasilkan barang sesuai pesanan yang dipesan oleh bank syariah sebagaiman spesifikasi sesuai dengan yang dipesan oleh pemesan awal/nasabah. ${ }^{13}$

Bai' istishna' adalah semacam kontrak khusus daripada bai' salam. Kebiasaan pada Bai' istishna' ini adalah digunakan pada bidang pembuatan barang yang dihasilkan baik dari tangan ataupun mesin dengan bahasa lain cemacam manufaktur. Oleh karenanya, ketentuan yang terjadi pada bai' salam dari segi aturan bai' istishna' juga melakukannya. Namun letak perbedaan yang lain dalam kriteria Bai' istishna' ini adalah pembayarannya beberapa kali bisa dilakukan oleh bank syariah. ${ }^{14}$

Kriteria secara umum

1) Ketentuan dan kriteria pada barang spesifikasinya harus jelas, rigid dan transparan.

2) Tidak boleh ada perubahan harga setelah terjadi kesepakatan.

3) Apabila ada perubahan terkait barang pesanan maka tambaha biaya ditanggung oleh nasabah atau pemesan barang.

${ }^{13}$ Ibid.

14 Heri Sudarsono, Bank Lembaga Keuangan Syariah (Yogyakarta: Ekonisia, 2003), hlm. 68. 
Hal ini bisa dilihat pada skema sebagai berikut:

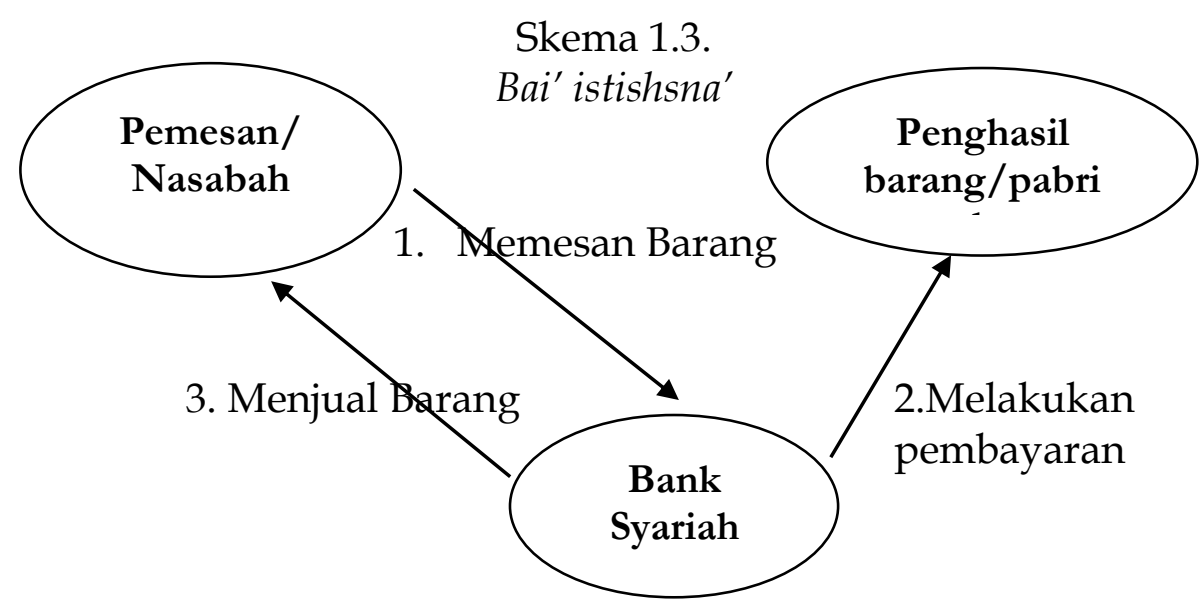

Perbedaan bai' istishsna' dan bai' salam.

\begin{tabular}{|c|c|c|c|}
\hline $\begin{array}{c}\text { Unsur } \\
\text { Pokok }\end{array}$ & $\begin{array}{c}\text { Pembiayaa } \\
\text { n Salam }\end{array}$ & $\begin{array}{c}\text { Pembiayaan } \\
\text { Istishsna' }\end{array}$ & Penjelasan \\
\hline Akad & $\begin{array}{c}\text { Barang } \\
\text { Pesanan } \\
(\text { Muslam } \\
\text { Fiih })\end{array}$ & $\begin{array}{c}\text { Barang atau Objek } \\
(\text { Mashnu') }\end{array}$ & $\begin{array}{c}\text { Faktor spesifikasi } \\
\text { barang sama- } \\
\text { sama bisa }\end{array}$ \\
\hline $\begin{array}{c}\text { Tsaman } \\
\text { / }\end{array}$ & $\begin{array}{c}\text { Dilakukan } \\
\text { setelah } \\
\text { akad }\end{array}$ & $\begin{array}{c}\text { Dapat dilakukan } \\
\text { ketika akad, dicicil } \\
\text { atau dibayar } \\
\text { dikemudian } \\
\text { hari/ditangguhka } \\
\text { n }\end{array}$ & $\begin{array}{c}\text { Ciri utama } \\
\text { perbedaan dari } \\
\text { keduanya terletak } \\
\text { pada cara } \\
\text { pembayarannya } \\
\text { yang berbeda }\end{array}$ \\
\hline $\begin{array}{c}\text { Akad } \\
\text { dalam } \\
\text { sifatnya }\end{array}$ & $\begin{array}{c}\text { Kaku } \\
\text { karena } \\
\text { hanya satu } \\
\text { ikatan }\end{array}$ & Fleksibel & $\begin{array}{c}\text { Dalam akad } \\
\text { salam kedua } \\
\text { belah pihak } \\
\text { sama-sama }\end{array}$ \\
\hline
\end{tabular}




\begin{tabular}{|l|c|c|}
\hline & & terikat sedangkan \\
akad istishna' \\
ikatannya \\
dilakukan dalam \\
rangka melinduni \\
pabrik/penghasil \\
barang dari sifat \\
atau tindakan \\
tidak \\
bertanggungjawa \\
b yang bisa jadi \\
akan dilakukan \\
oleh pemesan \\
barang baik \\
ketika barang \\
sedang \\
\\
& dikerjakan atau \\
& setelah barang \\
& selesai dihasilkan \\
\hline
\end{tabular}

\section{Kontrak Istishna' (kemitraan dalam manufaktur)}

Kontrak istiwhsna' cocok untuk memfasilitasi manufaktur atau pembuatan aset atas permintaan pembeli. Setelah produsen memproduksi aset atau properti untuk pembeli, maka terjadilah transaksi istishsna' . Kedua pihak, yakni pembeli dan pembuat, sepakat atas penetapan harga dan juga sepakat akan spesifikasi aset yang akan dibuat. Pada saat penyerahan barang, apabila aset tersebut tidak sesuai dengan spesifikasi, pihak yang memesan berhak untuk menarik kembali kontrakannya.

Salah satu fitur penting dari istishsna' adalah mode dan waktu pembayaran. Pembayarannya cukup fleksibel. Pembayaran tidak selalu harus di muka. Pembayaran juga tidak harus saat penyerahan barang. Kedua belah pihak dapat menyepakati jadwal pembayaran yang nyaman bagi kedua 
belah pihak dan pembayaran tersebut juga dapat dengan cicilan.

Seperti halnya bai' salam, istishsna' adalah kontrak penjualan di mana aset dibeli atau dijual sebelum barang tersebut tersedia. Walaupun demikian, perbedaan utama antara bai' salam dan istishsna' adalah: (i) aset dalam kasus istishsna' disyaratkan harus dibuat atau disusun; (ii) tidak ada persyratan pembayaran penuh pada saat kontrak/Pembiayaan; (iii) istishsna' dapat dibatalkan sebelum pembuat melaksanakan pembuatan, sedangkan bai' salam tidak dapat dibatalkan secara sepihak; dan yang terakhir (iv) terdapat fleksibelitas dalam waktu penyerahan barang dalam istishsna' juga memiliki potensi besar untuk diaplikasikan aspek pembiayaan di berbagai sektor dan industri. Aplikasi istishsna' yang sukses antara lain pembuatan pesawat terbang, lokomotif, dan industri pembuatan kapal, serta pembuatan alat berat. Kontrak istishsna' juga sesuai dengan industri konstruksi untuk pembangunan infranstruktur seperti jalan, bendungan, perumahan, ruko dan sekolah, dll. ${ }^{15}$

Ragam dari model-model pembiayaan istishsna' ini cenderung variatif. Memang dalam model pembiayaan pada pembiayaan istishsna' ini hampir mirip dengan pembiayaan salam, namun dalam pembiayaan istishsna' ini cenderung dilakukan akadnya pada pesanan barang-barang khusus, unik dan jarang tersedia di pasaran pada umumnya. Misalkan memesan sepeda motor dengan model dan warna yang tidak ada pada umumnya atau dengan spesifikasi tertentu sehingga berbeda dari pada barang pasaran. Biasanya ada ketentuan pembayaran angsuran berkala atas dasar harga pembelian total, yang seringkali didasarkan pada kemajuan aktual pembuatan barangnya. Dengan demikian, pembuat kapal dapat memperoleh kontrak pembelian kapal dengan harga tertentu

15 Zamir Iqbal, Abbas Mirakhor, Pengantar Keuangan Islam (Jakarta: Kencana Prenada Media Group, 2008), hlm. 110-111. 
dan dengan pembayaran angsuran selama prieode pembuatan kapal dari pembeli terakhir. Kontrak ini mirip sekali dengan pinjaman pembangunan gedung di Barat atau pembiayaan perantra lainnya.

Sama halnya dengan kontrak salam, kontrak istishsna' dapat dibuat secara langsung antara pabrik dengan pengguna terakhir. Dalam contoh-contoh ini, bank mengadakan kontrak istishsna' - baik dengan pembayaran lunas di muka maupun pembayaran angsuran - dengan pabrik pada satu pihak dan pembayaran angsuran murabahah dengan pengguna terakhir pada lain pihak. Keuntungan kotor yang diperoleh bank ditunjukkan oleh nilai pembayaran angsuran nilai sekarang dari pembayaran bertahap kepada pabrik, ditambah biaya administrasi yang dikenakan oleh bank. Dengan bank sebagai perantara, pabrik terbebas dari resiko kredit nasabah. Pengeluaran pabrik untuk mengamankan dirinya sendiri dari resiko kredit ini sama dengan keuntungan kotor yang diperoleh bank.

Dengan mengambil contoh dari transaksi yang penulis kaji, sebuah bank Islam mengadakan kontrak pembuatan barang-barang tertentu yang akan dikirimkan dalam 6 bulan dengan pabrik. Kontrak istishna' dengan pabrik mengharuskan serangkaian pembayaran bertahap kepada pabrik selama periode waktu 6 bulan. Pembeli barangnya telah ditunjuk oleh pabrik dan bank membuat kontrak yang mengharuskan pembeli ini membayar kepada bank. Pembeli tidak akan menerima pengiriman barang selama 6 bulan. Kontrak bank dengan pabrik adalah transaksi istishna', sedangkan kontrak bank dengan pembeli barang adalah kontrak salam. Harga pada kontrak istishna' mencerminkan resiko macetnya pekerjaan oleh pabrik dan tingkat kesempatan modal bank. Harga pada transaksi salam antara pengguna terakhir dengan bank mencerminkan resiko kredit jaminan bank sekaligus penggunaan alternatif terhadap uang oleh pengguna terakhir 
itu sendiri selama periode antara pembayaran tunai dengan pengiriman barang. ${ }^{16}$

\section{Pembiayaan Istishna'dalam Bank Syariah ${ }^{17}$}

Pembiayaan istishna'di bank syariah umumnya diterapkan pada pembiayaan untuk pembangunan proyek seperti: pembangunan proyek listrik, komunikasi, perumahan, gedung sekolah, sarana jalan danpertambangan. ${ }^{18}$ Pembiayaan istishna' sering diperuntukan dalam pembiayaan investasi misalnya pembiayaan untuk pembangunan gedung pabrik, sekolah, atau pesanan untuk pembelian aset lainnya. Ilustrasi berikut ini akan memperjelas pemahaman tentang aplikasi pembiayaan istishna' oleh bank syariah.

\section{Tamtsil Implementasi Pembiayaan Istishna'}

Pabrik Baru direncanakan akan di bangun oleh PT Maju Jaya Yogyakarta sebagai ekspansi perusahaannyadi daerah Klaten. Dana yang di butuhkan unuk melakukan pembangunan ini diperkirakan Rp 10.000.000.000,-. Karena keterbaan dana, PT Maju Jaya mengajukan pembiayaan istishna' kepada bank syariah sebesar Rp 10.000.000.000,-. Sedangkan Lahan yang telah dipersiapkan sampai pematangan tanah bernilai $\mathrm{Rp}$ 2.000.000.000,-.

Bank syariah bertindak sebagai penjual, untuk melaksanakan pembangunannya bank syariah tidak dilakukan sendiri, bank syariah melaksanakan pemesanan kepada kontraktor PT Arya Raya sebagai pelaksana pembangunan gedung untuk memenuhi kebutuhan pembeli akhir, yaitu PT Maju Jaya.

16 Frank E. Vogel \& Samuel L. Hayes, III, Hukum Keuangan Islam, Konsep, Teori dan Praktek, terj. (M. Sobirin Asnawi, ed.), (Bandung: Nusamedia, 2007), hlm. 224-225.

${ }^{17}$ Ibid.

${ }^{18}$ Ismail, Perbankan Syariah., hlm. 149-150 
Perincian dalam kasus ini dapat dihitung sebagai berikut:

1. Harga pesanan (bank syariah 10.000.000.000,- kepada PT Maju Jaya)

$\mathrm{Rp}$

2. Harga jual bank syariah kepada PT Maju Jaya (nasabah)

Rp 15.000.000.000,-

3. Margin keuntungan pembiayaan istishna

Rp 5.000.000.000,-

Unuk pembayaran oleh nasabah kepada bank syariah dilakukan dalam jangka waktu lima tahun. Terdapat keuntungan sebesar Rp 5.000.000.000,- yang akan dinikmati oleh bank syariah untuk jangka waktu lima tahun.

Perbankan syariah dapat melakukan Pembayaran kepada PT Arya Raya sekaligus di muka, sesuai termin penyelesaian pembangunan, atau diakhir pada saat pembangunan selesai. dalam kasus ini, pembayaran atas pesanan Istishna' dilakukanbanksyariah pada umumnya sesuai dengan termin penyelesaian pembangunan. ${ }^{19}$ Selain perbankan syariah, praktik istishna'sebenar sudah banyak dilakukan oleh lembaga-lembaga pembiayaan. Agar kita mendapatkan pandangan yang lebih utuh pelaksanaan istishna', berikut beberapa gambarannya;

Kegiatan Perusahaan Pembiayaan (selain perbankan syariah) berupa Pembiayaan Konsumen Berdasarkan Pembiayaan istishna'

Dalam transaksi istishna', umumnya terdiri dari tiga pihak, Pertama perusahaan pembiayaan bertindak sebagai pembeli dari suatu barang pesanan yang dipesan, Kedua, Produsen sebagai pembuat barang (disebut shani' II) untuk menyediakan obyek istishna'.Ketiga, adalah Pemesan atau Konsumen dari suau perusahaan pembiayaan. Pembiayaanistishna'ini, dilakukan setelah Pembiayaanistishna' antara perusahaan pembiayaan dan konsumen atau pembiayaan (mustashni')

${ }^{19}$ Ibid.,hlm. 151. 
Dengan memberikan pembiyaan kepada konsumen berdasarkan Pembiayaanistishna', maka timbul hak dan kewajiban yang melekat pada perusahaan pembiyaan yaitu:20

a) mendapatkan pembayaran sebesar harga jual barang secara angsuran sesuai yang diperjanjikan dari konsumen atau pemesan (mustashni').

b) Mengembalikan objek istishna'jika konsumen sebagai pemesan (mustashni') tidak dapat membayar angsuran sesuai yang diperjanjikan.

c) Memilih produsen yang akan menjadi pembuat (shani') objek istishna'.

d) Menyediakan objek istishna'yang disesuaikan dengan spesifikasi yang diminta dan disepakati bersama dengan konsumen.

e) Menjamin objek istishna'sempurna (tidak cacat danatau tidak berfungsi).

Di sisi lain pembuat (shani' II) juga mempunyai hak dan kewajiban tersendiri, antara lain adalah sebagai berikut:

a) Mendapatkan pembayaran dari konsumen pembiayaan sesuai dengan yang janjikan.

b) Menyediakan objek istishna'(sesuai spesifikasi yang disepakati bersama dengan perusahaan pembiayaan).

c) Menjanjikan objek istishna' tidak yang cacat dan atau tidak berfungsi.

d) Mewujudkan objek istishna'disesuaikandengan waktu yang diperjanjikan.

Sedangkan untuk konsumen sebagai pihak yang berkepentingan atas barang konsumtif tertentu, juga mempunyai hak dan kewajiban berupa: menerima objek istishna'dengan kondisi baik dan siap dioperasikan sebagaimana spesikasi yang dijanjikan, menerima atau mendapatkan objek istishna' sesuai dengan waktu yang dijanjikan, dan melakukan

${ }^{20}$ Abdul Ghafur Anshori, Penerapan Prinsip Syariah (Yogyakarta: Pustaka Pelajar, 2008), hlm. 176-180 
pembayaran angsuran atau biaya lainnya sesuai dengan yang dijanjikan.

Objek istishna' (masnu') sendiri, harus dapat memenuhi beberapa ketentuan, yaitu: spesifikasinyajelas, dapat diakui sebagai utang,barang harus halal, penyerahannya dilakukan kemudian haridengan waktu dan tempat penyerahan harus ditetapkan berdasarkan kesepakatan, jika terdapat cacat atau tidak sesuai kesepakatan, maka pemesan mempunyai hak untuk memilih (khiyar) untuk melanjutkan atau malah membatalkan Pembiayaan.

Menetapkan harga jual terhadap objekistishna' wajib didasarkan pada kesepakatan antara satu pihak dengan pihak lainnya (dalam hal ini antara perusahaan pembiyaan atau bank syariah dan konsumen sebagai pembeli atau pemesan (mustashni')) di awal perjanjian dan tidak boleh berubah sampai selesai masa istishna'. Untuk pembayaran, pihak konsumen (mustashni') dapat dilakukan dengan cicilan sejak Pembiayaan ditanda tangani atau dengan cara pembayaran lain yang disepakati.

Dalam praktiknya, Perjanjian pembiayaan konsumen yang dibuat berdasarkan Pembiayaan istishna'akan memuat beberapa hal sebagai berikut:

1. Identitas (baik bank syariah maupun konsumen).

2. Spesifikasi objek istishna' (mashnu') (nama, jenis, jumlah, ukuran, tipe dan kualitas objek)

3. Harga jual dan cara pembayarannya.

4. Ketentuan jaminan dan asuransi.

5. Jangka waktu.

6. Lokasi dan waktu penyerahan.

7. Ketentuan mengenai biaya-biaya yang ditanggung oleh masing-masing pihak apabila terdapat kerusakan, kehilangan atau tidak berfungsinya objek istishna'

8. Ketentuan pengakhiran transaksi yang belum jatuh tempo.

9. Hak dan tanggung jawab masing-masing pihak. 
Sedangkan untuk bank atau perusahaan pembiayaan setidaknya meliputi: surat permohonan realisasi istishna', keterangan kesanggupan menyelesaikan barang pesanan dari produsen (shani'II), besaran Pembiayaan istishna'surat persetujuan prinsip (offering letter) dari bank atau perusahaan pembiyaan,barang atau objek pesanan, perjanjian pengikatan jaminan, tanda terima uang dari produsen sebagai pembuat (shani' II), dan tanda terima barang oleh konsumen sebagai pembeli atau pemesan (mustashni').

Beberapa Perusahaan pembiayaan konsumen yang saat ini menerapkan prinsip syariah dalam kegiatan operasionalnya yaitu: PT. al-Ijarah Finance Indonesia, PT. Federal International finance, PT. Mandala Multifinance TBK, dan PT. Trus Finance Indonesia TBK. Selain itu juga dilaksanakan oleh PT. Wahana Ottomitra Multiarta, PT. Fortuna Multi Finance, PT. Kapitalinc Finance, Trihamas Finance dan PT. Amanah Finance.

Dengan demikian dapat dikatakan bahwa upaya penerapan prinsip syariah dalam kegiatan perusahaan pembiyaan, khususnya pada kegiatan konsumen sudah ada sejak sebelum adanya regulasi dari Bapepam dan LK terkait dengan perusahaan pembiayaan berdasarkan prinsip syariah. 


\section{Potensi Masalah Pembiayaan Istishna'}

Dalam setiap bisnis, kita tidak luput dari potensi resiko yang menyertainya, termasuk juga dalam Pembiayaan dengan akad istishna. beberapa risiko yang mungkin timbul terhadap bank syariah, seperti kegagalan menyelesaikan pesanan (misal, kontraktor gagal menyerahkan rumah pada waktu yang dijanjikan, tidak sepenuhnya spesifikasi yang di minta terpenuhi, atau debituryang mengalamigagal bayar pada masa kontrak. beberapa faktor yang menentukan risiko gagal bayar dalam akad istishna bisa di idenifikasi sebagai berikut :

1. Bank bukanlahyang memiliki material yang digunakan developer (produsen dan subkontraktor) untuk memproduksi aset (dalam kasus istishna paralel), hal ini tentu menyebabkan bank tidak memiliki hak klaim terhadap aset ketika terjadi kasus wanprestasi. Salah satu Cara memitigasi risikonya adalah diperlukan sesuatu yang menjadi pengikat terhadap produsen atau subkontraktor sehingga dapat memaksanya memenuhi kontrak.

2. Risiko pengiriman keterlambatan pengiriman barang dari subkontraktor sehingga berakibat bank tidak mampu menyelesaikan produksi barang sesuai jadwal akibat. Cara mitigasi risiko ini adalah bank harus melakukan pengawasan dengan ketat agar potensi terjadi wanprestasi atau keterlambatan pengiriman barang dari subkontraktor bisa di minimalisir.

3. Terdapatpotensi risiko kualitas yang bisa berbeda atas pengiriman barang inferior oleh subkontraktor yang berakibat pada ketidaksesuaian kesepakatan antara bank dan pemesan. Cara mitigasinya adalah bank mesti meminta jaminan kualitas dari subktraktor yang di tunjuk.

Selain hal di atas, PembiayaanIstishna' ini jika dilihat dari segmentasinya, maka akan terlihat bahwa tidak semua segmen masyarakat membutuhkan. Pembiayaan ini hanya bisa memenuhi atau memfasilitasi konsumen yang mempunyai 
kebutuhan pembiayaan yang bersifat jangka pendek (misalnya sampai pesanan rumah selesai dibangun). Konsumen dengan ipologi ini, biasanya adalah masuk kategori konsumen menengah ke atas. Pejanjian istishna' akan melibatkan beberapa pihak,yang umumnya minimal 3 pihak, Semakin banyak tahapan kontrak perjanjian, maka semakin rumit hal yang harus diperhatikan, dan tentu membutuhkan proses yang tidak sederhana.

\section{Penutup}

Berdasarkan penjelasan terkait kontrak istishna'di atas, ada beberapa hal yang bisa kita simpulkan;

Pertama: Pembiayaanistishna'merupakan Pembiayaan dalam bentuk pemesanan pembuatan barang tertentu dengan kriteria dan persyaratan tertentu yang disepakati antara pemesan dan penjual diawal kontrak dengan pembayaran di awal, di akhir dan bahkan di cicil sesuai dengan perjanjian.Objek istishna' (mashnu') haruslah barang yang halal, dapat diakui sebagai utang, harus dapat dijelaskan spesifikasinya, penyerahannya dilakukan kemudian dengan waktu dan tempat penyerahan harus ditetapkan berdasarkan kesepakatan.Dalam hal terdapat cacat atau tidak sesuai kesepakatan, maka pemesan memiliki hak memilih (khiyar) untuk melanjutkan atau membatalkan Pembiayaan yang di mintanya.

Kedua: praktik pembiayaan istishna' dilembaga keuangan biasanya melibatkan pihak ketiga sebagai subkontrakor atau penyedia barang. Ketiga: menyertai mode pembiayaan ini, juga terdapat potensi risiko yang mengiringinya, utamanya karena melibatkan 3 pihak sekaligus untuk mewujudkan pembiayaan istishna' ini. 
Pembiayaan Istishsna' dan Implementasinya di Perbankan Syariah

\section{Daftar Pustaka}

Abdul Ghafur Anshori, Penerapan Prinsip Syariah, Yogyakarta: Pustaka Pelajar, 2008.

Abdurrahman al-Jaziri, al-figh ala mazdahib al-arba'ah, Beirut: Darul Qalam, vol II. tt.

Abu Bakar Ibnu Mas'ud al-Kasani, al-Bada'i was Sana'i fi Tartib al-Shara'I, Bairut: Darul Kitab al-Arabi, edisi ke-2.

Ahmad Ifham Sholihin, Buku Pintar Ekonomi Syariah, Jakarta: Kompas Gramedia, 2010.

Ahmad Warson Munawwir, Kamus al-Munawwir Arab-Indonesia Terlengkap, Yogyakarta: Ikapi, 1997, cet. Keempat belas.

Ali Ahmad As-Salus, Musi'ah al-Qadaya al-fighiyah al-Muashirah wal-iqtishad al-Islami, Mesir: Badrul Kutub al-Mishriyah, 2006.

Dwy Suwiknyo, Kamus Lengkap Ekonomi Islam, Yogyakarta: Total Media, 2009.

Frank E. Vogel \& Samuel L. Hayes, III, Hukum Keuangan Islam, Konsep, Teori dan Praktek, terj. (M. Sobirin Asnawi, ed.), Bandung: Nusamedia, 2007.

Hendi Prabowo. Heri Sudarsono, Istilah-istilah Bank dan Lembaga Keuangan Syariah, Yogyakarta: UII Press, 2006, cet keempat.

Heri Sudarsono, Bank Lembaga Keuangan Syariah, Yogyakarta: Ekonisia, 2003.

Ilyas Anton Ilyas, al-qomus al-ashri, Shunduq Barid, 954.

Ismail, Perbankan Syariah, Jakarta: Kencana Prenada Media Group, 2011.

Muhammad Syafiie Antonio, Bank Syariah, Jakarta: Ikapi, 2011, cet. Kedelapan.

Nurul Hak, Ekonomi Islam Hukum Bisnis Syariah, Yogyakarta: Sukse Offset, 2011.

Zamir Iqbal, Abbas Mirakhor, Pengantar Keuangan Islam, Jakarta: Kencana Prenada Media Group, 2008. 